\title{
A Study of Linguistics Landscape Towards Tourism Enterpreneur Language Ability at Simanindo District, Samosir Regency, North Sumatera Province
}

\author{
Rahmat Darmawan \\ Politeknik Pariwisata Medan \\ E-mail: radarmawan69@gmail.com
}

\begin{abstract}
This research is aim for finding and describing the language skill of tourism actor in Simanindo sub-district which reflected on the results of using language in public by using linguistic landscape approach or known as LL. The research method which used in this research is descriptive and qualitative method. Basically, qualitative method observe the use of language on LL, review the form and meaning of language morphology and multilingual morphological situation as an international tourist area. In this research we observed that the use of language in all public spaces included street names, welcome greetings, directions, tourism business signs and so on and provided questionnaires for tourism actors regarding language skills. By using qualitative method, Data obtained will be fuller, deeper, trustworthy and meaningful so that the research objectives can be achieved. The findings of the research: language morphology dominated by the form of words and phrases. In the linguistic situation the most dominant form of bilingual are mixing between the use of Indonesian and English. The meaning of the language contained in LL in Simanindo District is oriented to denotative and connotative meaning. Somewhat rare idiomatic meaning for dominant use of language in the LL is informative. The language skills of tour operators are generally still lacking. This is evident from the morphology of words, phrases, clauses and sentences in Indonesian and English by not applying the rules of writing and good translation. There is a difference between the use of $L L$ made by the government and private institutions. $L L$ by the government has uniformity at the linguistic and non-linguistic level while the independent tourism actors tend to produce the original language according to the wishes of each local community. This becomes significant with the language as the first component encountered by tourists in the tourist area. Language will determine whether the tourists will linger or leave the area immediately. Recommendation: (1) It should be a good linguistic planning of the use of language in the $L L$ in Simanindo. (2) The need to reduce the language awareness of tourism. (3) It should be cooperation between the relevant institutions to provide training and counseling language in favor of language skills (language competence) tourism actors.
\end{abstract}

Keywords - Linguistic Landscape; the use of language; language skills; tourism players.

I. INTRODUCTION

and produce texts that are meaningful according to the Language competency is a very broad term that situation in which they are used.

masters' linguistic or grammatical competencies, competency Language competency is best developed in the discourse, sociolinguistic competencies or socio-cultural context of learning activities or assignments where language competencies, and what might be called textual is used for real purposes, in other words, can be used in competence.Language competency relate to language practical applications.One of language competency that can knowledge and the ability to use that knowledge to interpret be realized is the application of language skills that are 
reflected in the use of language in public spaces or referred to as landscape linguistic or lanskaplinguistik abbreviated as LL.

Simanindo sub-district is one of the development areas of tourist areas in the Lake Toba area. Precisely located in Samosir Regency, Simanindo began to stretch along with the direction of tourism development in the area of Lake Toba.

There are several tourist objects and attractions in Simanindo sub-district. Some tourist objects and attractions are TuktukSiadong Tourism Village, Tomok Village with Sigale-Gale attractions on Raja Sidabutar's Old Tomb, Siallagan Village with BatuPersidangan tourist attractions, and so on.

The existence of objects and tourist attractions that are so diverse requires good management of tourism doers. Good management is not only how to manage attractions, cleanliness of tourist objects, management of tourist objects and other matters relating to local revenue (PAD). More than that is the management of human resources for tourism doers. Tourism doers in the broadest term are all components of society that are in a tourist attraction that acts as a service. Tourism doers are managers who work to serve all tourist needs on tourist objects and attractions.

Study of landscape linguistic can be seen as a sub-field of both sociolinguistics and applied linguistics, written in "written forms" of language in public spaces (GorterdanCenoz, 2006:2) mainly focusing on "multilingual settings"(Coulmas, 2009:14). According to Landry and Bourhis (1997:25), the linguistic landscape refers to the use of language on public road signs, billboards, street names, place names, commercial shop signs, and general signs in government buildings ... from those given by region, region, or agglomeration urban area". But the field of study of linguistic landscapes has evolved from the analysis of commercial and government signs found on the streets of metropolitan cities, ethnic environments and small cities. Among the various objects of study of linguistic landscapes are schools (Dagenais et al 2009; Dressler 2015), train station (Kunci 2003; Backhaus 2006), science laboratory (Hanauer 2009); apartment building (Jaworski and Yeung 2010), postcard (Jaworski 2010), public monument (Shohamy and Waksman 2009; Abousnnouga and Machin 2010), and cyberspace
(IvkovicdanLotherington 2009; Troyer 2012; Jones 2011). Linguistic landscapes have been investigated from a number of perspectives, such as language policy and language ideology (Sloboda 2009; Marten 2010), national and ethnic identity (Trumper- Hecht 2009; Dray 2010), language and education awareness (Dagenais et al., 2009), marginalization of minority communities (Lou 2010), mixed language code and hybridization (Huebner2009), language learning material (Cenos\&Gorter 2008; Dagenais et al 2009; Bolton 2012; Sayer 2010), and tourism and the commodification of culture (Kallen 2009; Piller 2010; Moriarty 2015).

Tourist attractions are a complex place where language contacts occur. Indeed the creation of tourist spaces depends heavily on the linguistic landscape of these spaces (Bruyei-Olmedodan JuanGarau 2009; Jaworski 2010; Moriarty 2015). The use of language for tourism promotion is important as a source of information for potential tourist arrivals. The use of language involves people in making decisions about the purpose they want to travel to a tourist destination (Salim et al 2012).

Research about language and tourism is in the realm of linguistic and tourism studies. Many studies come from within sociolinguistics, where researchers have considered how the social context in terms of what is faced by tourists when first visiting tourist destinations reflects or challenges the theory of language used (Cohen and Cooper 1986; Heller 2003; Boudreau and White 2004; Manca 2008; Jaworski 2010). Other related work in the sociolinguistic realm considers the role of language in representation from a broader cultural perspective, and other identities in tourist destinations (Pietikäinendan Kelly-Holmes 2001; Couplanddkk 2005; Cos 2006; Drozdzewski 2011; ThurlowdanJaworski 2011; Strand 2012, 2013; Ploner 2013).The study of linguistic landscapes and tourism has contributed to providing an understanding of how language and tourism are interconnected and related to each other and how cultural perspectives and other identities in tourist destinations are presented in tourist public spaces.

Study of the linguistic landscape in tourist destinations are very rare. However, according to the author, there are several researchers who have examined the linguistic landscape. Among them is a study entitled A LingiuiticLandsacpe Study of 
Signage on Nimmanhemin Road, A Lanna Chiang Mai Chill-Out Street (Thongtong, 2016)show the results of the research show that the linguistic landscape on Ninmanhemin Road represents a tourist space. Ninmanhemin Road is an 800-meter road. Research on signage shops, restaurants, spas and all types of tourism businesses shows a tourist area. This study applies quantitative methods to calculate all languages in the public space. Furthermore, applying qualitative methods to examine the language, types of language, literary and rhetorical devices used in signage that shows a tourist space. The research above is a reference for writers to develop research in Simanindo sub-district, Samosir Regency.

\section{METHOD}

\section{A. Place and Time of Research}

The research was conducted in Simanindo

Sub-district, Samosir Regency. Simanindo subdistrict is one of the key tourism areas within the Lake Toba Destination area. The other two are Pangururan District and Balige City in Tobasa Regency. The study was conducted for approximately two months starting April 23 to June 23, 2018.

\section{Data Analysis Method}

In analyzing data, the method used is descriptive qualitative. This approach was carried out aimed at describing in full the use of language in public spaces in Simanindo sub-district, once seeing the phenomenon of the language skills of tourism actors in Simanindo sub-district. This study applies a mixture of quantitative and qualitative research methods. The quantitative approach involves the classification of signs collected according to the type of business / business represented and the language found.In the case of multilingual signs, this study applies Reh's idea of the bilingual distribution of cross-language information, and Kress and Van Leeuwan about spatial grammar to determine the relative superiority of each language. The qualitative aspect of this research method is to investigate the types of linguistics, literary and rhetorical tools or strategies that help create and determine the tourist space.

Data was collected in Simanindo subdistrict, especially in tourist objects and attractions that have cultural and natural nuances. Signage from hotels, restaurants / cafés, souvenir shopping centers,

\section{B. Method of Data Collection}

In obtaining data, the author applies several methods, including the following:

a. Interview

The author conducted an interview to the creator / creator of LL signage in Simanindo sub-district.

b. Questionnaire

The author distributes questionnaires to language makers in public spaces in Simanindo District. The data asked is related to lingual units such as language forms (words, phrases, clauses and sentences) and language forms in public spaces in a multilingual (mono / bi / multilingual) framework.

c. Documentation

The author takes photos of the use of language in public spaces related to the problems raised in this study.

d. Literature review

Frameworks of concepts and theories are obtained through library research. Previous studies and studies relating to linguistic landscapes and language skills were used as the foundation and foundation for this study.

information on attractions, appeal boards, do's and don't's, and so forth. There are about ... signs used for analysis in terms of language choices and linguistic devices. Linguistic, literary and rhetorical devices found in signage include transliteration, a mixture of lexical, hybrid structures, acronyms, homophones, personifications, speech acts, and politeness strategies.

Each data in the form of LL images on several tourist objects in Simanindo sub-district is sorted by form and meaning. Furthermore, interviews and questionnaires were given to tour operators to explore insight into linguistic knowledge associated with LL language use. At the end, the pictures and answers to interviews and tourist actors questionnaire on language skills are analyzed and it will be known whether the language performance in LL in Simanindo sub-district is comparable or not with the language skills of tourist doers in Simanindo.

\section{RESULTS AND DISCUSSION}

The language skills of tourist doers can be realized through language performance both orally 
and in writing. As explained in the previous chapters, this research is limited to the performance of written language displayed on the use of LL in public spaces in the Simanindo area. The use of language in LL is a manifestation of the language skills of tourist doers.

The use of language in LL focuses on four tourist objects and attractions. The four tourist attractions and attractions are: 1) Stone Objects in the Siallagan Village, 2) Tuk-TukSiadong Tourism Village, 3) HutaBolon Museum; and 4) The Old Tomb of King Sidabutar in Tomok Village.

LL's approach in examining the language skills of tourism actors includes linguistic and nonlinguistic language skills analysis. Language skills are not only the ability to use foreign languages such as English but in the use of Indonesian. Furthermore, in examining further, the LL study will apply a multimodal approach.

A multimodal approach is applied because LL uses more than one semiotic mode or in other words delivered through various methods at the same time in the form of the use of language in the public space. Therefore the multimodal approach is very appropriate.

As described in Chapter I, this study will explore the use of LL in three aspects. First is how the language is used. Next is what are the meanings contained in the LL usage. Third is what are the functions of LL displayed on public spaces in tourist objects and attractions in Simanindo. These three aspects will describe the language skills of tourist actors embodied in the use of LL in tourist objects and attractions in Simanindo.

\section{LL at the BatuPersatuan Tourism Object, HutaSiallagan}

In the picture below we can see LL welcome to the Stone / Stone Chair Trial in Siallagan Village, Simanindo.

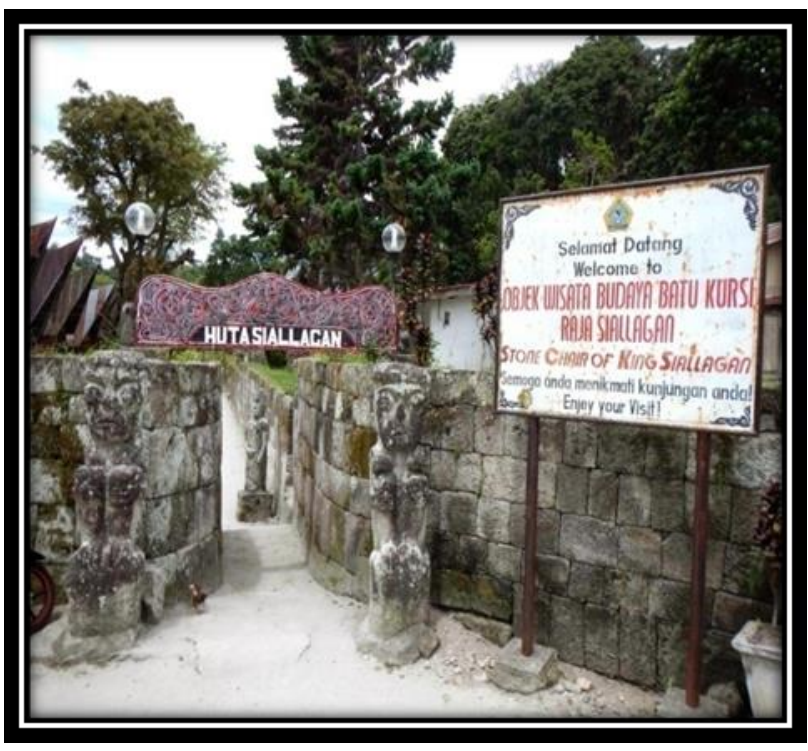

Fig. 1 Source: Processed Author, 2018

Picture LL Welcome to the Stone Chair of the Siallagan Village

On LL above, the form of language used is seen. Morphologically there are phrases, clauses and sentences. There is no word form in the LL. The phrase "Welcome", the Clause "Raja Siallagan Chair Stone Cultural Attraction" and the phrase "May you enjoy your visit". Each lingual unit shows the use of the official language of the Indonesian language. Seeing from the language element, the creator of signage is a tourism agent or stakeholder in this case is the Tourism Office.

The media used is in the form of metal or iron media with a frame that was previously planned. The red color in the Clause "BatuSiallagan Chair Stone Cultural Attraction" shows that LL makers want to highlight the name of the tourist attraction. The white base in LL also wants to contrast the writing and the media so that it can be seen remotely. So, the creator of LL is the manager in this case is the tourism agency or the local government.

From a multilingualism perspective, LL above applies bilingual namely the use of Indonesian and English. The phrase "Welcome to" and the clause "Stone Chair of King Siallagan" are followed by the clause "Enjoy Your Visit". Use in LL Welcome is bilingual or bilingual. So, as a tourist attraction on an international scale, tourist actors or sign makers in HutaSiallagan have created signage in two languages there are Indonesian and English. 


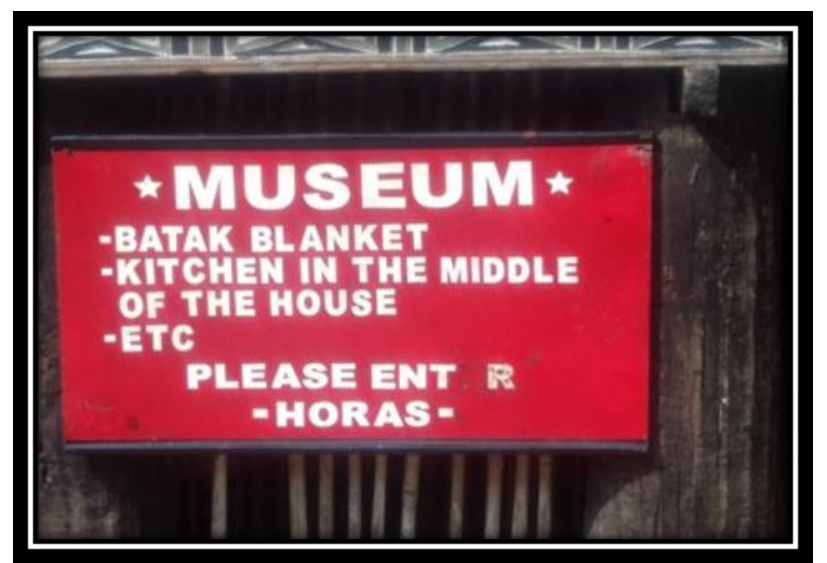

Fig. 2 Source: Processed Author, 2018

Picture of LL Stone Trial at HutaSiallagan

The figure in LL shows the monolingual use of English. There is one phrase "HORAS" as a symbol of greeting in Batak language to show identity. A red background with white writing means wanting to attract visitors to enter the museum. Visitors can see the writing from a distance so they can decide to enter the museum. Morphologically, the form of language is dominated by phrases and clauses. All writing is written in capital letters indicating dominance and power. The inscription "MUSEUM, BATAK BLANKET, KITCHEN IN THE MIDDLE OF THE HOUSE, ETC, PLEASE ENT R, HORAS" are all written in capital letters.

The signage creator makes English as a marker that foreign tourists always visit the tourist attraction of HutaSiallagan. The language ability of tourist doers in the HutaSiallagan object has applied the use of English.

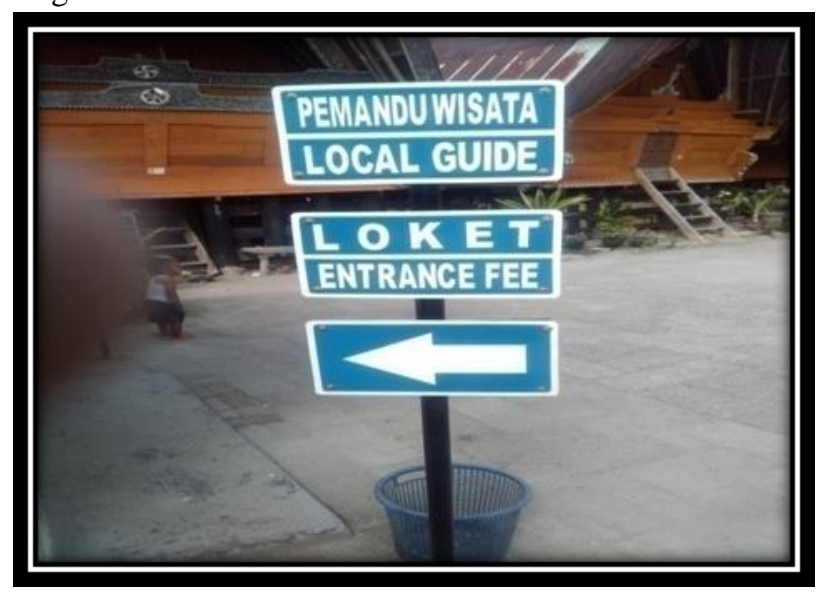

Fig. 3 Source: Processed Author, 2018

LL picture in HutaSiallagan

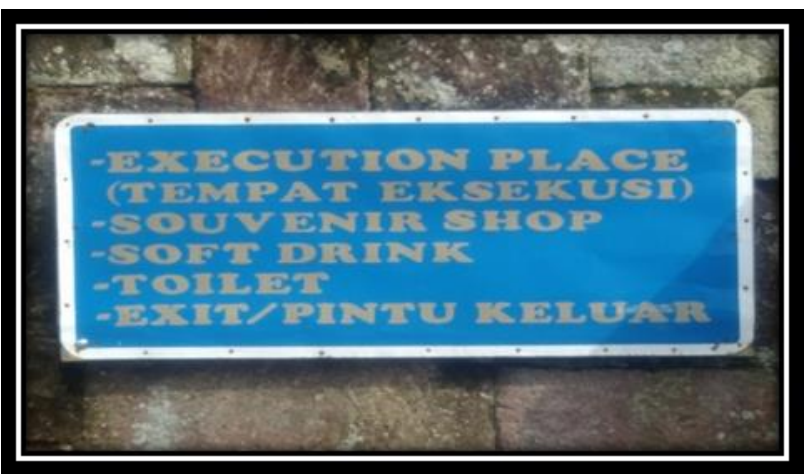

Fig 4 m Source: Processed Author, 2018

LL picture in HutaSiallagan

In Figure 4.4 and Figure 4.5, it is seen that LL uses language in several places in the BatuPersatuan Tourism Object, HutaSiallagan, which uses English and Indonesian bilingual.

The language skills of tourist doers are clearly seen here using two languages; English and Indonesian. The color selection of LL media is blue with white writing (Figure 4.4) and the media is blue with brown writing (Figure 4.5) indicating the inconsistency of LL makers. The blue color indicates that a place is still at a considerable distance.

The form of language is morphologically dominated by phrases and clauses. There are no sentences in Figure 4.4 and Figure 4.5. As a tourist area, the form of using bilingual English and Indonesian can be seen clearly. In the picture in the phrase "Tour Guide" is translated into "Local Guide" and the phrase "Lockets" translated into "Entrance Fee" indicates the use of phrases and clauses. There is no use of sentences.

While in Figure 4.5, LL uses language that shows several places in HutaSiallagan. The phrase "Execution Place" and the phrase "Exit / Exit" are two groups of words translated. While the phrase "Souvenir Shop, Soft Drink and Toilet" are not translated respectively. Whether the manager / signage maker does not understand the meaning of the words or the words and phrases in Figure 4.5 LL are understood by tourists.

\section{LL at the Tomb of Raja Sidabutar, Tomok}

The form of language in LL at the Tomb of King SidabutarTomok seems to have clear consistency with a visible size and contrasting colors that attract the attention of visitors. 
Fig. 5 Source: Processed Author, 2018

Picture LL at the Tomb of Raja Sidabutar, Tomok

In the picture above, it can be analyzed that the signage maker is not a community of perpetrators of tourism or the manager of the tourist attraction of the Tomb of King Sidabutar. Judging from the orange color of LL media, font size, black on letters, LL makers certainly use consultants in making it.

The lingual form of LL is dominated by the form of the phrase "Mushalla", "Sigale-gale" with the arrow "" as a non-linguistic sign which means indicating direction.

The following picture is the use of language in the LL nameplate of the Tomb of King Sidabutar.

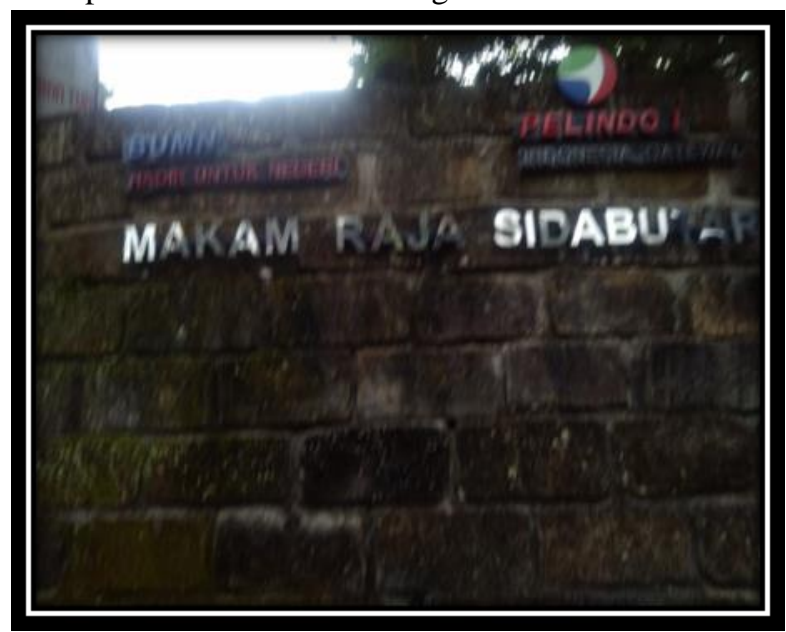

Fig. 6 Source: Processed Author, 2018

Image LL Nameplate of the Tomb of Raja Sidabutar, Tomok

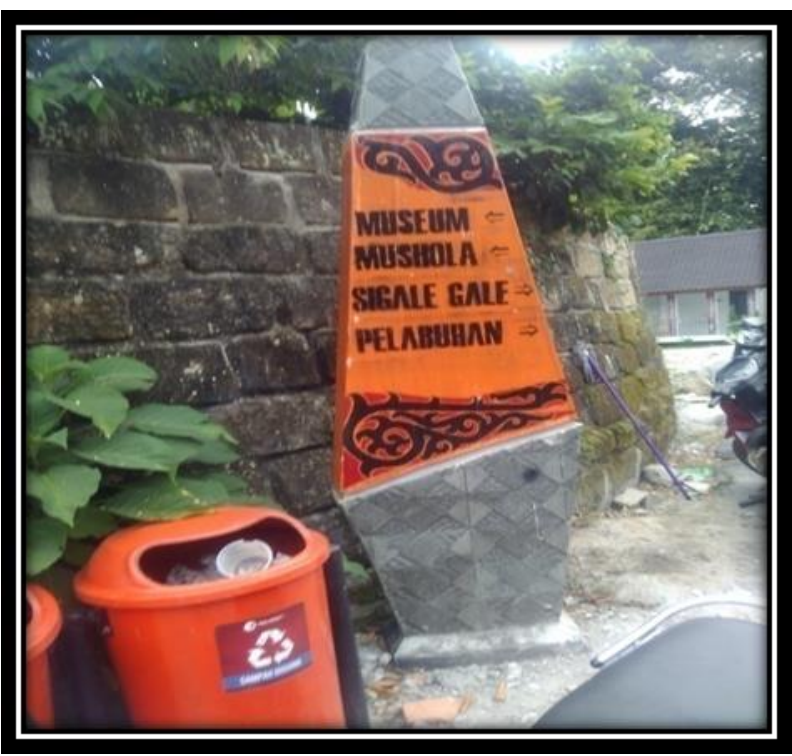

The signboard LL Tomb of King

Sidabutar is not written in English. The meaning is a form of Indonesian language monolingual language. Morphologically only in the form of the clause "MAKAM RAJA SIDABUTAR".

Metal and aluminum materials in the LL nameplate indicate that the creators of LL are not local tourism actors, but government and private organizations that want to contribute in the form of customer social responsibility (CSR). LL object nameplate was made by one of Pelindo I's StateOwned Enterprises (BUMN). There are also logos and company names.

From the explanation above, it can be seen that the quality standards for making / creating LL in good public spaces tend to involve third parties in this case the government / BUMN and the private sector. This is because LL standards require funding sources that are not small including language analysis. 


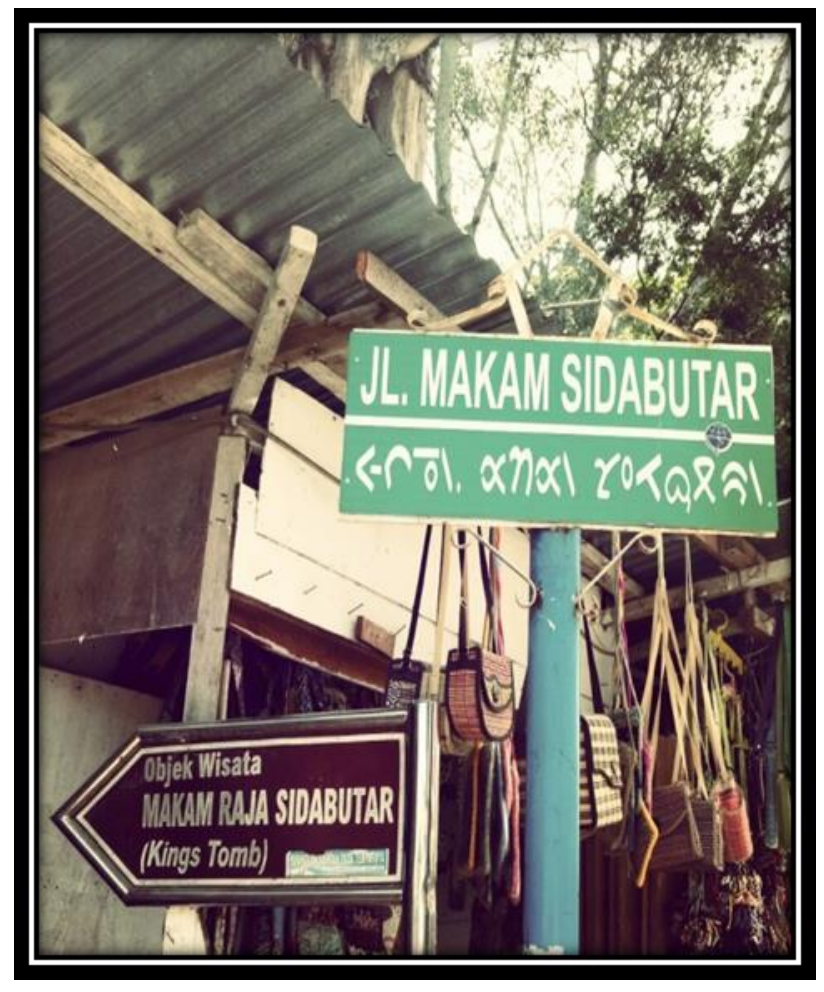

Fig 7 Sumber: www.tripadvisor.com, 2017

Picture of LL Nameplate of the Tomb of Raja Sidabutar, Tomok

Picture LL "street names and nameplate" attractions were created with variations in design and color. LL was created by the government. The media is green with a lingual form using Indonesian "JL. MAKAM SIDABUTAR "and its translation in Batak language (SuratBatak).

Media LL "nameplate as well as directions" with the basic color of chocolate using international coloring standards, namely the basic color of brown with white writing shows the direction of an object and tourist attraction in a tourism area. The English phrase "Kings Tomb" in LL shows the existence of the object as a world-class tourist object.

However, in Figure 4.9 below, we can see how the LL nameplate with various tourist information objects is put together. LL readers feel confused if they have to read fast.

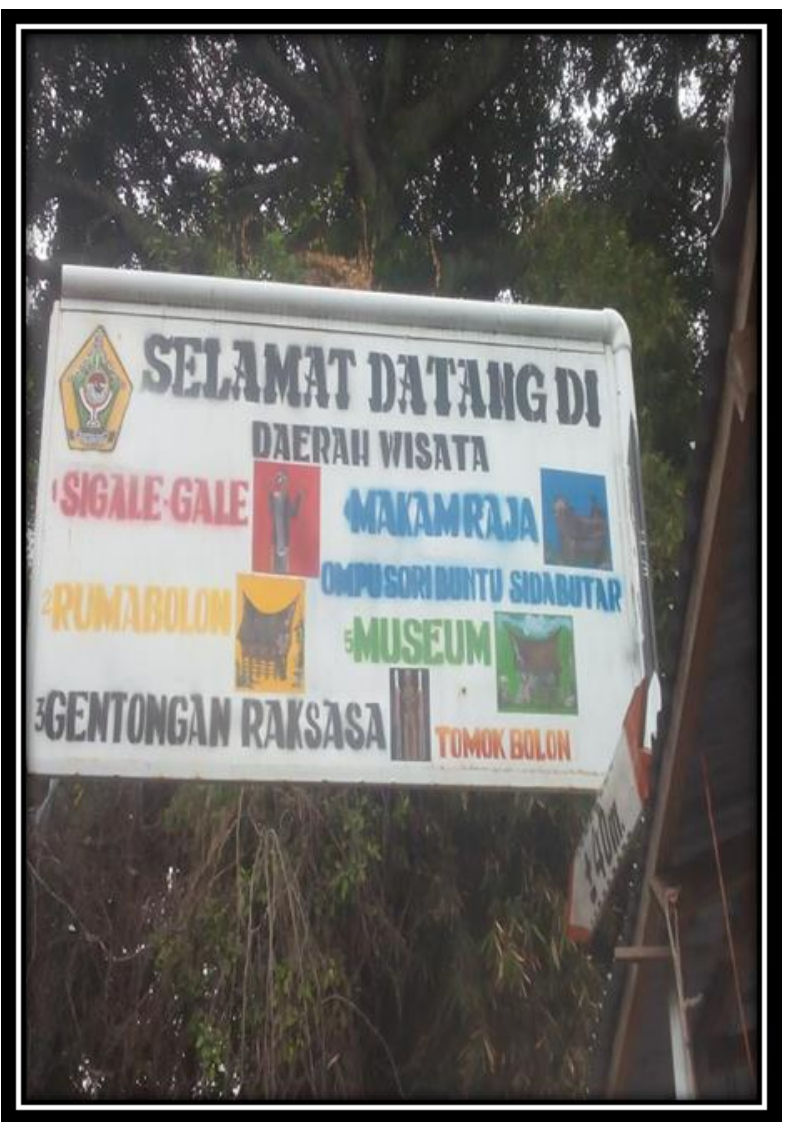

Fig 8 Sumber: www.tripadvisor.com, 2017

Gambar LL SelamatDatang di Daerah Wisata, Tomok

There are five names of attractions at once at one LL welcome. The form of the use of the preposition "DI" in the phrase "SELAMAT DATANG DI" is very inappropriate. There is no clause or sentence form. The sentence is needed to provide an explanation of the tourist attraction. But in reality, the most lingual forms of words, phrases and clauses are used.

As an area with frequent language contact like in Tomok, Figure 4.9, LL does not provide any use of foreign languages. All written in one language, that is Indonesian. 


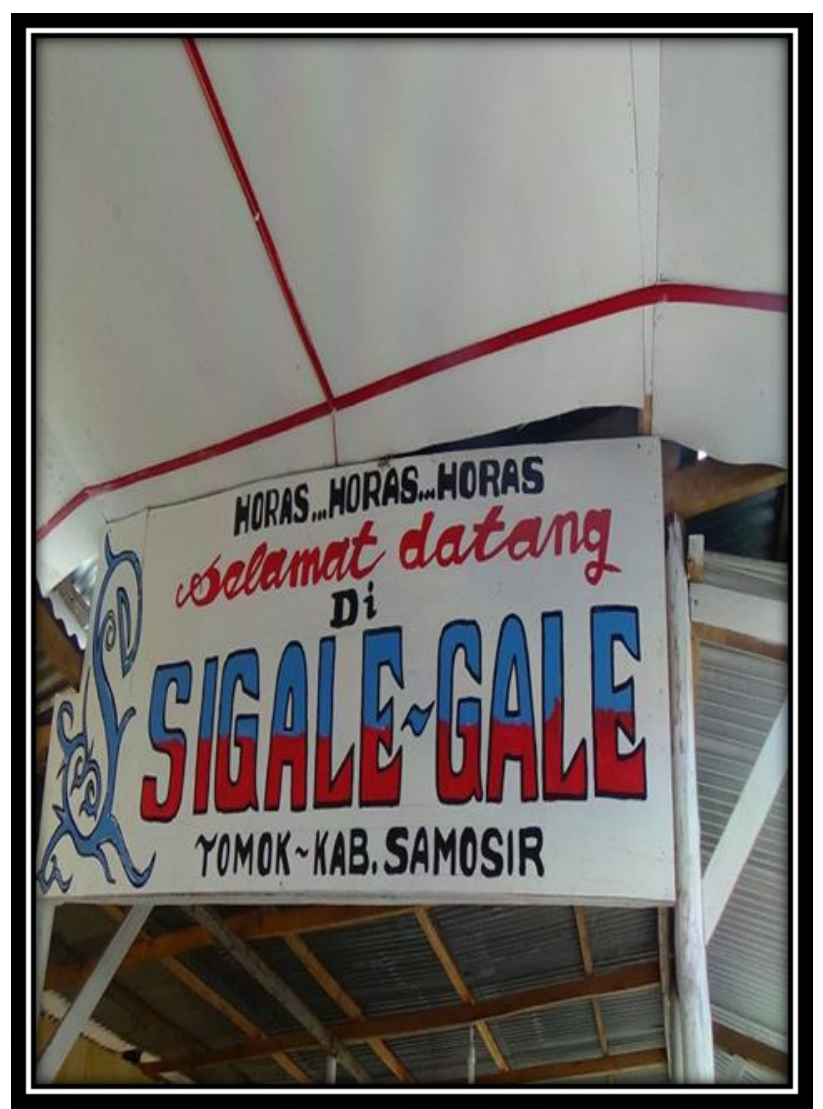

Fig 9 Source: Bali, 2017

Picture of LL Welcome to SiGale-Gale Attractions, Tomok

The white color as the base color with the combination of red, black and blue in the writing reflects the color pattern of the ethnic Batak. The form of the phrase "Horas" until written three times shows intimacy and warmth in welcoming guests or tourists.

The absence of the use of English in Figure 4.10 LL selamatdatang indicates a lack of understanding of tourism actors. The monolingual form of Indonesian seems to be aimed only at domestic tourists.

The creator of signage in the picture above is clearly from the local community. This can be seen from the media used by the LL creator. In addition, from the lingual welcome unit, it does not apply good language usage rules.

LL made by the government or an official institution is somewhat different from LL made by tour operators / site managers and tourist objects.

The following picture is LL made officially by a government agency or tourism agency.

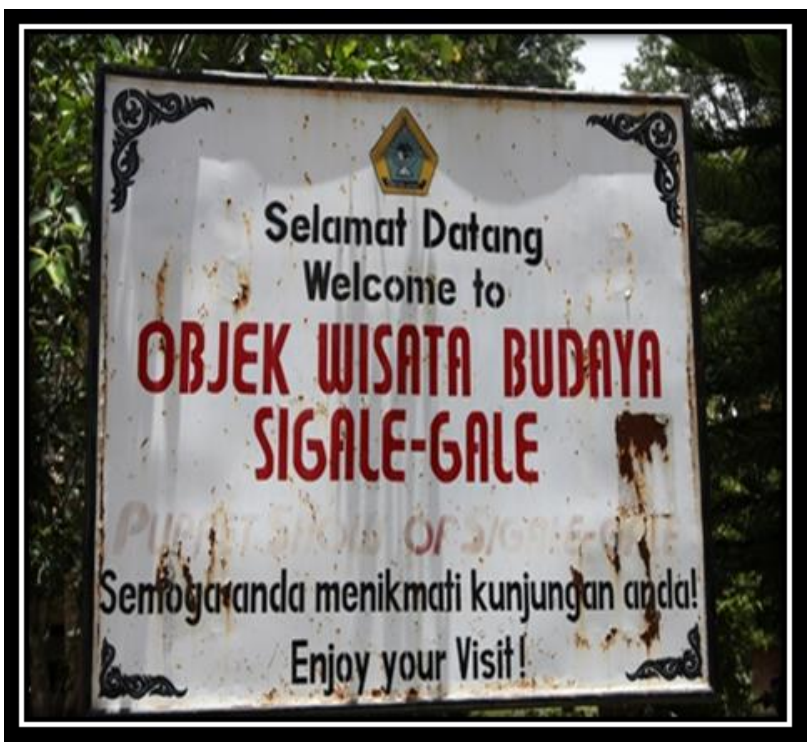

Fig.10 Source: Processed Author, 2018

Picture of LL Speech Welcome to Sigale-Gale Cultural Tourism Object

On the picture of LL, a welcome note shows that the media used is metal or iron and not a board or plywood with a white base. The color composition that is not conspicuous, namely black and red in the words "OBJEK WISATA BUDAYA SIGALE GALE" and the black color in other writings want to highlight the name of the site or tourist attraction.

The phrase "Hope you enjoy your visit!" Is translated with a sentence in English "Enjoy your Visit!". There is an exclamation point (!) In the two sentences above. Exclamation point (!) means command. Can it be applied in LL meaningful information for visitors. LL informational functions are not in the form of orders, but only in positive statements.

The following picture is LL in the tourist attraction of the Old Tomb of King Sidabutar. This LL combines all informative and symbolic functions. 


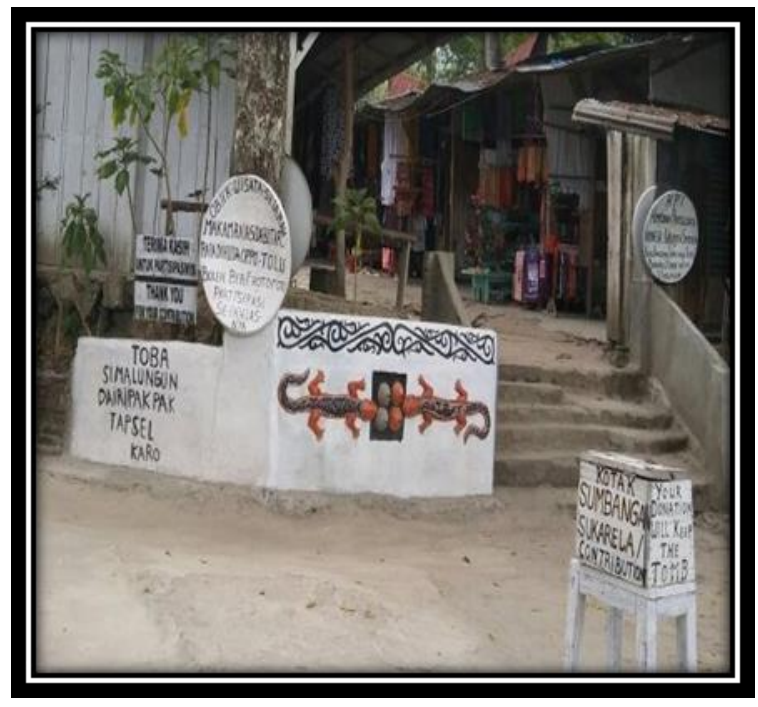

Fig. 11 Source: www.Tripadvisor.com

Figure of LL in the Old Tomb of King Sidabutar

Table. 1

KNOWLEDGE ABOUT THE LINGUISTIC LANDSCAPE CONCEPT

$\mathrm{n}=20$
\begin{tabular}{|l|l|l|l|}
\hline No & Answer & Amount & Percentage \\
\hline 01 & $\begin{array}{l}\text { a. Yes } \\
\text { b. No }\end{array}$ & - & \\
\hline & Total & 20 & $100 \%$ \\
\hline
\end{tabular}

From the answers of the respondents one hundred percent did not know the concept of using language in public spaces. This means that it can be concluded that all respondents did not know the use of language in public spaces or the linguistic landscape.

Table. 2

LANGUAGE COMPETENCY

$\mathrm{n}=20$

\begin{tabular}{|l|l|l|l|}
\hline No & Answer & Amount & Percentage \\
\hline 02 & a. Yes & 8 & $40 \%$ \\
& b. No & 12 & $60 \%$ \\
\hline & Total & 20 & $100 \%$ \\
\hline
\end{tabular}

From table 4.3 above it can be seen that language knowledge tends to be not good because only eight people or $40 \%$ say knowing, while $60 \%$ or 12 respondents say they do not know the language competency concept.

Table. 3

THE USE OF INDONESIAN LANGUAGE WELL $\mathrm{n}=20$

\begin{tabular}{|l|l|l|l|}
\hline No & Answer & Amount & Percentage \\
\hline 03 & a. Yes & 5 & $25 \%$ \\
& b. No & 15 & $75 \%$ \\
\hline & Total & 20 & $100 \%$ \\
\hline
\end{tabular}

Table 4

THE USE OF ENGLISH WELL

$\mathrm{n}=20$

\begin{tabular}{|l|l|l|l|}
\hline No & Answer & Amount & Percentage \\
\hline 04 & a. Yes & 2 & $10 \%$ \\
& b. No & 18 & $90 \%$ \\
\hline & Total & 20 & $100 \%$ \\
\hline
\end{tabular}

Based on respondents' answers to the use of English properly, as many as 18 people or about $90 \%$ answered no. Only two people know the use of English well. This is in accordance with the analysis of the LL language usage form. The conclusion is that the mastery of English in tourism actors is still relatively low.

Table 5

MAKING THE NAME BOARD ON TOURISM BUSINESS $\mathrm{n}=20$

\begin{tabular}{|l|l|l|l|}
\hline No & Answer & Amount & Percentage \\
\hline 05 & a. Yes & 16 & $80 \%$ \\
& b. No & 4 & $20 \%$ \\
\hline & Total & 20 & $100 \%$ \\
\hline
\end{tabular}

Respondents' answers to the knowledge of making nameplate in tourism businesses show results that are counterproductive to language performance in LL. About 16 people or $80 \%$ know the making of a signboard. While only 4 people or $20 \%$ said they did not know the concept of making a signboard.

The author concludes that tourists tend to know the making of nameplate. Knowledge of making nameplate is only based on intuition and experience. Knowledge based on procedures and methods that are burdensome in LL making tend not to be well mastered.

Table 6

THE PURPOSE OF MAKING THE NAME BOARD $\mathrm{n}=20$

\begin{tabular}{|l|l|l|l|}
\hline No & Answer & Amount & Percentage \\
\hline 06 & a. Yes & 20 & $100 \%$ \\
& b. No & - & - \\
\hline & Total & 20 & $100 \%$ \\
\hline
\end{tabular}

From the respondent's answer to the purpose of making the nameplate is 100 people $100 \%$ 
said they knew the purpose of making the nameplate. In general, tourism actors or anyone business owners must know the purpose of making a nameplate, which can be known by consumers as information and so on.

However, when the question about the rules for making name board was submitted, it turned out that only about 6 people knew that $30 \%$ the rules for making a good name board.

This proves that even though all respondents know the purpose of making a name board, only about $30 \%$ know the rules for making a standard signboard. As shown in the table below

Table. 7

THE RULES FOR MAKING THE NAME BOARD $\mathrm{n}=20$

\begin{tabular}{|l|l|l|l|}
\hline No & Answer & Amount & Percentage \\
\hline 07 & a. Yes & 6 & $30 \%$ \\
& b. No & 14 & $70 \%$ \\
\hline & Total & 20 & $100 \%$ \\
\hline
\end{tabular}

This means that all of this has happened in making the name board is only based on experience and origin of likes and not based on standard rules.

Table. 8

LANGUAGE PRINCIPLE ON THE NAME BOARD $\mathrm{n}=20$

\begin{tabular}{|l|l|l|l|}
\hline No & Answer & Amount & Percentage \\
\hline 08 & a. Yes & 9 & $45 \%$ \\
& b. No & 11 & $55 \%$ \\
\hline & Total & 20 & $100 \%$ \\
\hline
\end{tabular}

The table above shows answers that tend to ignorance of the principle of using good language on the name board. This can be proven by the number of respondents ranging from 11 people or around $55 \%$ not knowing while $45 \%$ or 9 people answered knowing.

Table. 9

KNOWLEDGE ABOUT WORDS, PHRASE, CLAUSE AND SENTENCE

$\mathrm{n}=20$

\begin{tabular}{|l|l|l|l|}
\hline No & Answer & Amount & Percentage \\
\hline 09 & a. Yes & 3 & $15 \%$ \\
& b. No & 17 & $85 \%$ \\
\hline & Total & 20 & $100 \%$ \\
\hline
\end{tabular}

Respondents' answers in table 4.10 above prove that tourism actors tend not to know the difference in words, phrases, clauses and sentences in LL making because only about $15 \%$ or 3 respondents answered yes, while 17 people or around $85 \%$ answered that they did not know the definitions the lingual unit.

Table. 10

TRANSLATION OF WORDS, PHRASE, CLAUSE AND SENTENCE FROM INDONESIAN TO ENGLISH $\mathrm{n}=20$

\begin{tabular}{|l|l|l|l|}
\hline No & Answer & Amount & Percentage \\
\hline 10 & a. Yes & 7 & $35 \%$ \\
& b. No & 13 & $65 \%$ \\
\hline & Total & 20 & $100 \%$ \\
\hline \multicolumn{2}{|c|}{ The next question was asked to the }
\end{tabular}

tourism doers about the translation of lingual units from Indonesian to English. From the 20 respondents, who answered yes as many as 7 people or $35 \%$, while those who answered were not as many as 13 people or $65 \%$. This proves that language skills in the context of translation are still lacking. This phenomenon is clearly illustrated in language performance in public spaces.

Table. 11

GET LINGUISTIC TRAINING

$\mathrm{n}=20$

\begin{tabular}{|l|l|l|l|}
\hline No & Answer & Amount & Percentage \\
\hline 11 & a. Yes & 4 & $20 \%$ \\
& b. No & 16 & $80 \%$ \\
\hline & Total & 20 & $100 \%$ \\
\hline
\end{tabular}

A total of 4 respondents or about $20 \%$ answered yes and $80 \%$ answered that they did not get linguistic training.

This is clearly and convincingly proven from the use of language in LL in almost all tourism business owners. Some respondents said they had attended linguistic training.

Table. 12

DESIRE TO ATTRACT FOREIGN TRAVELERS WITH THE MAKING OF NAME BOARDS IN ENGLISH

$\mathrm{n}=20$

\begin{tabular}{|l|l|l|l|}
\hline No & Answer & Amount & Percentage \\
\hline 12 & a. Yes & 15 & $75 \%$ \\
& b. No & 5 & $25 \%$ \\
\hline & Total & 20 & $100 \%$ \\
\hline
\end{tabular}

From the table above, it appears that the LL maker's desire to attract foreign visitors by making a signboard in English. About 75\% stated yes and meant that the desire to attract foreign guests was realized in the creation of English in LL tourism actors from both the private and government elements. 
Table. 13

PENGETAHUAN KONSEPPEWARNAAN DALAM PEMBUATAN PAPAN NAMA

$\mathrm{n}=20$

\begin{tabular}{|l|l|l|l|}
\hline No & Answer & Amount & Percentage \\
\hline 13 & a. Yes & 1 & $5 \%$ \\
& b. No & 19 & $95 \%$ \\
\hline & Total & 20 & $100 \%$ \\
\hline
\end{tabular}

Respondents' answers are only about 5\%

or 1 person who knows the concept of coloring in making nameplate. Color is language. Color can provide an understanding of the overall use of language.

About 19 people or $95 \%$ said they did not know the concept of coloring in creating LL. It can be concluded that almost all tourism actors do not know the concept of coloring as a part of language.

All respondents in table 4.15 answered that they wanted to show their identity when making a signboard. This is also evident in the performance of language use in public spaces in Simanindo. Nearly all uses of language in LL provide characteristics as the identity of tourism business owners. Tourists want to show identity. It can't be denied anymore.

Table. 14

KEINGINAN MENUNJUKKANIDENTITAS KETIKA MEMBUAT PAPAN NAMA

$\mathrm{n}=20$

\begin{tabular}{|l|l|l|l|}
\hline No & Answer & Amount & Percentage \\
\hline 14 & a. Yes & 20 & $100 \%$ \\
& b. No & - & - \\
\hline & Total & 20 & $100 \%$ \\
\hline
\end{tabular}

So, all respondents want to show their tourism business identity to visitors or tourists.

Table. 15

MENDAPATKAN PERHATIAN DARI PEMERINTAH $\mathrm{n}=20$

\begin{tabular}{|l|l|l|l|}
\hline No & Answer & Amount & Percentage \\
\hline 15 & $\begin{array}{l}\text { a. Yes } \\
\text { b. No }\end{array}$ & - & - \\
\hline & Total & 20 & $100 \%$ \\
\hline
\end{tabular}

The table above shows that not one respondent answered ever getting attention from the government or other relevant agencies about making a sign on the use of LL on sites and attractions in Simanindo sub-district.

The results of the analysis on the subtitles of language skills shown by the exposure of fifteen tables prove that: a) the language skills of tourist actors are still relatively low; b) the purpose of making LL is to show identity while providing information to tourists and visitors; c) the use of English is only limited to attracting foreign tourists and prestige; and 4) have never received serious attention from the government and other relevant agencies regarding the standardization of language use in public spaces in Simanindo sub-district.

\section{CONCLUSION}

'Based on the analysis and discussion in the previous section, in Chapter V, the following writer can conclude:

a. The language skills of tourists in making LL from the point of view of language in LL language use in SimanindoSubdistrict can be seen from two perspectives. The first is from a morphological perspective. Morphologically, the satual lingual form of language using LL is in the form of phrases and clauses. Very few forms of language are in sentence form.

In this case, signage makers do not yet have language skills that can describe the state of an international tourist attraction. This can be seen from phrase patterns and clauses that do not use language usage rules, both Indonesian and English.

An example is the use of the phrase "Please enter Horas" not in accordance with the rules of use in English. This is Indonesian words in English. In addition, there is a tendency for signage to be made by government institutions such as local government and tourism doers. This is indicated by the structure of phrases, clauses and sentences in LL. So, there is a low and high variety of usage levels. The low variety is made by the tourism community, such as restaurant owners, restaurants, cafes, beauty salons and so on. While the high variety is in the use of LL on welcome greetings, nameplate and others

The second is from the perspective of multilingualism. As a tourist area, the language skills of tourism actors are good, with most LL uses written in bilingual or two languages, Indonesian and English. There are also LL written in the form of Batak language. But the ability to translate as part of language skills cannot be fully said to be good. An example is the translation of the phrase "Tiket" to "Entrance Fee" and the clause / sentence 
"SelamatmenikmatikunjunganAnda" to "Feel the miracle" which is not equivalent to adequate translation.

b. The meaning of the language contained in the use of LL is divided into denotative meaning and connotative meaning. Travelers do not feel they are in an international tourist area. Thirst for information provided causes tourists to feel they must leave the area immediately. The meaning reflected in the use of LL in Simanindo is limited to denotative and connotative meanings only. Denotafif meaning is found in almost all LL in Simanindo District. Whereas connotative meanings are found in some LL such as "Your donation will keep the tomb". This sentence has implications for connotative meaning that the manager has the habit of begging. This is not in line with the psychological understanding of tourists that this location is not a place for begging.

c. The language skills of tourists cannot be said to be good. This can be seen from the use of lingual elements in everything naming LL. The language skills of tourists are only seen from the use of lingual units, namely words, phrases, clauses and sentences. In fact, the language ability of the perspective of the linguistic landscape approach is to apply the use of non-linguistic units such as: frame, media color, font size, font color, and so on. In the use of LL at Simanindo, tourism actors in plain sight only apply the use of lingual units only. As a result, there is an uneven use of LL. This inconsistency raises the chaos of the use of language in public spaces in Simanindo. Thus, it can be said that the ability of the community of tourism actors (stakeholders) in language is still low.

Suggestion: From the conclusions above, the writer can give constructive suggestions and input to improve the use of language in the tourist area of Simanindo. In an effort to improve the language skills of tourism actors in SimanindoSubdistrict associated with the linguistic landscape approach, suggestions and inputs can be given as follows:

a. Improving the language skills of tourism actors can be improved through consistent and directed training patterns. Public awareness of the use of language (language awareness) must be improved. Language awareness can be realized by mutual agreement in the form of language policy originating from the tourism actors and the government or regional government. The use of language forms must be uniform and directed in accordance with good language rules. Not only in Indonesian, but English plays a very significant role in giving the impression of a tourist area. Language is something that is first encountered by tourists.

b. Improving the ability of language actors in tourism from the point of view of giving meaning is to arrange all LL uses in Simanindo uniformly. The meaning of LL is not only illustrated by lingual units. Nonlinguistic units such as frames or frames, colors, LL media, font size should be uniform. The trick is to provide training and socialization through language institutions or language consultants. Give examples of a tourist area such as in Japan and Korea that have applied the uniformity of LL use for all tourist areas. Meaning that is not only denotative and connotative, but broader meanings such as informative and symbolic meanings can be realized in the future.

c. The language skills of tourism actors can be improved if the vision is shared between the government, tourism managers and the community. Each tourist actor should be provided with a standard dissemination of the continuous use of language. The evaluation of the existing LL usage is absolutely necessary. Setting changes to LL usage should be done from now on. If not, then the use of LL in SimanindoSubdistrict clearly shows the language skills of tourist actors who are still not well organized. By itself it will still have an impact on the negative impression that is reflected from the tourists. Thirst for information satisfaction through LL usage will continue to be experienced by tourists. Therefore, the evaluation of changes in all LL uses in the Simanindo area must be absolutely implemented.

\section{ACKNOWLEDGMENT}


The author would like to thank the director of the field tourism academy for his help and support so that the publication of the results of the research on "KajianLanskapLinguistikterhadapKemampuanberba hasaPelakuWisata di KecamatanSimanindo, KabupatenSamosir" can be published.

\section{REFERENCES}

AlWI, H., ET. AL. (2003). TATA BAHASABAKUBAHASAINDONESIA. JAKARTA:PUSAT BAHASA DAN BALAI PUSTAKA.

Backhaus, P. (2006). Multilingualism in Tokyo: A look into the linguistic landscape. International Journal of multilingualism, 3(1), 52-66 (special issue edited by D.Gorter).

Backhaus, P. (2007). Linguistics Landscapes. A comparative study of urban multilingualism in Tokyo. Clevedon, UK: Multilingual Matters.

Blue GM, Harun M (2003). Hospitality Language as Professional Skill. English for Specific Purposes, 22: 73-91.

Bolton, K. (2012). World Englishes and linguistic landscapes. WorldEnglishes, 31(1), 30-33. doi:10.1111/j.1467971X.2011.01748.x

Cenoz, J., \&Gorter, D. (2006). Linguistic Landscape and minority languages. International Journal of Multilingualism, 3(1), 67-80 (special issue edited by D.Gorter)

Dagenais, D., Moore, D., Sabatier, C., Lamarre, P., \& Aramand, F. (2009). Linguistic landscape and language awareness. In E. Shohamy\& D. Gorter (Eds.), Linguistic landscape:Expanding the scenery (pp. 253-269). New York, NY: Routledge.

Dray, S. (2010). Ideological struggles on signage in Jamaica. In A. Jaworski\& C. Thur- low (Eds.), Semioticlandscapes: Language, image, space (pp. 102-122). London, UK: Continuum.

Jaworski, A. (2010). Linguistic landscapes on postcards: Tourist mediation and the sociolinguistic communities of contact. Sociolinguistic Studies 4/3.469- 594.

Jaworski, A. \& Yeung, S. (2010). Life in the Garden of Eden: the naming and imagery of residential Hong Kong. In Shohamy, E., Ben-Rafael, E. \& Barni, M. (eds.). Linguistic Landscape in thecity (pp. 153-181). Bristol: Multilingual Matters.

Kress, G. \& van Leeuwen, T. (2006). Reading Images: the grammar of visual design. New York: Routledge

Kress, G, \& T. Van Leeuwen. (2002). Colour as a semiotic mode: Notes for a grammar of colour. Visual Communications (1) : 343 .
Kress, G. \& Van Leeuwen, T. (2001). Multimodal Discourse The Modes and Media of Contemporaray Communication. Great Britain: Arnold.

Kress, G. \& Van Leeuwen, T. (1998). Front Pages: (The Critical) Analysis of Newspaper Layaout. In Bell, Allan. and Garret, Peter (Eds), Approaches to Media Discourse. Oxford: Blackwell.

Kress, G. (2009). Multimodality: a Social Semiotic Approach to Contemporary Communication. London: Routledge.

Landry, R., \& Bourhis, R.,Y. (1997). Linguistic Landscape and Ethnolinguistic Vitality: An Empirical Study. Journal of Language and Social Psychology, 16, (1), 23-493.

Sirikhan S, Prapphal K (2011). Assessing Pragmatic Ability of Thai Hotel Management and Tourism Students in the Context of Hotel FrontOffice Department. ASIAN EFL J. Professional Teaching Articles 53: 72-94.

Srisuruk, P. (2011). Politeness and Pragmatic Competence in Thai Speakers of English. Unpublished Ph.D. dissertation. Australia: Newcastle University. STP Bali. Kurikulum STP Bali. http://www.stpbali-int.ac.id/in/kurikulum- manajemenkepariwisataan.html).

Thongtong, T., (2016). A linguistic Landscape Study of Signage on Nimmanhemin Road, A Lanna Chiang Mai Chill-Out. MANUSYA: Journal of Humanities, $\quad$ Special Issue No.22. Thailand: Chulalongkorn University. 